\title{
Pengaruh Prinsip-Prinsip Good Governance Terhadap Tingkat Kesehatan LPD pada LPD Se-Kecamatan Abiansemal
}

\author{
Ni Made Madani Hapsari ${ }^{1}$ \\ I Dewa Nyoman Wiratmaja ${ }^{2}$
}

\author{
${ }^{1}$ Fakultas Ekonomi dan Bisnis Universitas Udayana (Unud), Bali, Indonesia \\ email: madanihapsari9@gmail.com/Tlp:081236360685 \\ ${ }^{2}$ Fakultas Ekonomi dan Bisnis Universitas Udayana (Unud), Bali, Indonesia
}

\begin{abstract}
ABSTRAK
Good Governance merupakan tata kelola yang terdiri dari transparansi, akuntabilitas, responsibilitas, independensi, dan kewajaran dalam upaya perbaikan kinerja perusahaan. Tujuan penelitian ini adalah mengetahui pengaruh transparansi, akuntabilitas, responsibilitas, independensi dan kewajaran terhadap tingkat kesehatan LPD. Penelitian ini dilakukan di seluruh LPD se-Kecamatan Abiansemal. Jumlah sampel yang diambil sebanyak 34 orang ketua LPD, dengan metode probability sampling. Pengumpulan data dilakukan melalui wawancara, observasi dan dokumentasi. Teknik analisis yang digunakan adalah Analisis Regresi Liniear Berganda. Ditemukan bahwa hanya transparansi yang berpengaruh signifikan pada tingkat kesehatan LPD, sedangkan faktor lainnya seperti akuntabilitas, responsisbilitas, independensi dan kewajaran berpengaruh tidak signifikan pada tingkat kesehatan LPD. Hal ini menunjukkan disaat transparansi menjadi fokus perhatian manajemen, maka akuntabilitas, responsibilitas, independensi dan kewajaran dipandang sebagai sesuatu yang wajib untuk diterapkan oleh manajemen LPD.
\end{abstract}

Kata kunci: good governance, tingkat kesehatan LPD

\begin{abstract}
Good Governance is governance that consists of transparency, accountability, responsibility, independence, and fairness in an effort to improve company performance. The purpose of this study to determine the effect of transparency, accountability, responsibility, independence and fairness on the health level of LPD. This research was conducted in all LPDs in Abiansemal District. The number of samples taken was 34 chairmen of LPD, with probability sampling method. Data collection is done through interviews, observation and documentation. The analysis technique used is Multiple Liniear Regression Analysis. Found that only transparency has a significant effect on the health level of LPD, while other factors such as accountability, responsiveness, independence and fairness have no significant effect on the health level of LPDs. This shows when transparency is the focus of management's attention, accountability, responsibility, independence and fairness are seen as something that must be applied by LPDs management.
\end{abstract}

Keywords: good governance, healht level of LPD

\section{PENDAHULUAN}

Negara Indonesia merupakan suatu negara yang sedang berkembang, Salah satunya yaitu dalam bidang perekonomian. Perekonomian akan menjadi dasar untuk mewujudkan keberhasilan pembangunan dibidang lainnya. Keberhasilan 
dari pembangunan di bidang perekonomian akan tercapai apabila masyarakat secara optimal mampu mengembangkan usaha mikro kecil dan menengah (UMKM). Peran UMKM dalam meningkatkan perekonomian suatu daerah sangatlah penting. Partisipasi aktif dari masyarakat dan pemerintah sangat diperlukan untuk mewujudkan kemandirian UMKM dalam berusaha baik ditingkat Kabupaten/Kota maupun pedesaan.

Khususnya di Bali perkembangan pariwisata telah mampu meningkatkan kondisi perekonomian masyarakat Bali terutama masyarakat yang tinggal di daerah pariwisata. Pada tingkat Desa, disamping memiliki Desa Dinas yang diakui secara nasional, Bali juga memiliki Desa Adat/Desa Pekraman yang bersifat tradisional yang lingkupnya dalam hubungan sosial budaya dan keagamaan. Dilihat dari sudut pandang perkembangan usaha yang ada di Bali, diperlukan adanya pemberdayaan ekonomi rakyat guna mengetahui ekonomi lokal yang dimiliki di daerahnya masing-masing. Setiap kegiatan usaha yang dijalankan tidak terlepas dari peran serta bantuan dari pemerintah melalui jasa - jasa perkreditan seperti bank dan lembaga keuangan lainnya.

Salah satu lembaga keuangan non-bank yang diterapkan di Indonesia, khususnya di Bali adalah Lembaga Perkreditan Desa (LPD). Untuk mewujudkan kemandirian Desa Pekraman dalam mengelola kekayaan Desa, pemerintah Bali pada tahun 1984 telah mengeluarkan Surat Keputusan (SK) Gubernur No.972 Tahun 1984 tentang Pendirian Lembaga Perkreditan Desa di Provinsi Daerah Tingkat I Bali. Proyek pendirian LPD mulai dilakukan dan keberadaan LPD diatur dibawah Peraturan Daerah (PERDA) yakni PERDA Provinsi Bali No.8 Tahun 
2002 tentang LPD, dan di perbaharui lagi dengan PERDA Provinsi Bali No.3 Tahun 2007 tentang LPD dan terakhir diubah dengan PERDA Provinsi Bali No.4 Tahun 2012 tentang Perubahan Kedua atas PERDA Provinsi Bali No.8 Tahun 2002 tentang LPD.

LPD merupakan salah satu bentuk dari sistem desentralisasi yang diterapkan pemerintah dalam rangka menyelenggarakan pemerintah yang efektif, efisien dan bertanggung jawab. Sistem desentralisasi merupakan bentuk penyerahan wewenang dari pemerintah pusat kepada pemerintah daerah untuk mengurus rumah tangganya sendiri berdasarkan prakarsa dan aspirasi dari rakyatnya dalam kerangka Negara Kesatuan Republik Indonesia (NKRI). Dengan adanya desentralisasi ini, maka muncullah otonomi bagi suatu daerah. LPD merupakan suatu badan usaha yang unik karena LPD hanya ada di Bali dan dikelola berdasarkan falsafah adat dan budaya Bali yang sangat dipengaruhi oleh agama mayoritas di Bali, yaitu agama Hindu. Sangat sulit untuk membedakan antara adat dan agama pada masyarakat Bali karena setiap kegiatan keagamaan selalu melibatkan adat.

Kabupaten Badung merupakan salah satu dari Kabupaten dan Kotamadya yang ada di wilayah Provinsi Bali dengan luas wilayah 418,52 $\mathrm{km}^{2}$ terdiri dari 6 (enam) kecamatan yang sampai saat ini telah memiliki 122 LPD(Badung, 2015). Kabupaten Badung juga tercatat sebagai kabupaten yang secara rutin melakukan pertemuan seluruh LPD yang ada di Kabupaten Badung untuk tetap mengontrol kinerja LPD sehingga diharapkan pengelola LPD yang ada di Kabupaten Badung untuk tetap mengontrol kinerja LPD sehingga diharapkan pengelola LPD jauh dari 
Ni Made Madani Hapsari dan I Dewa Nyoman Wiratmaja. Pengaruh ...

praktek korupsi, kolusi, dan nepotisme. Pada Rapat Paripurna DPRD Bali Tahun 2017, I Nyoman Parta menyatakan dari 122 unit LPD di Kabupaten Badung, 79 LPD dinyatakan kondisi sehat, 22 LPD dinyatakan cukup sehat, 9 LPD dinyatakan kurang sehat, 4 LPD dinyatakan tidak sehat, serta 8 LPD dinyatakan bangkrut (Kabar Nusa, 2017).

Ketidaksehatan LPD ini disebabkan oleh kurangnya pemahaman kerja dari para pengurus LPD dalam mengelola LPD, dan masih sering ditemukan beberapa oknum LPD yang melakukan kecurangan di dalamnya (Dewi, 2014). Kinerja perusahaan merupakan suatu gambaran tentang kondisi keuangan suatu perusahaan yang dianalisis dengan alat - alat analisis keuangan, sehingga dapat diketahui mengenai baik buruknya keadaan keuangan suatu perusahaan yang mencerminkan prestasi kerja dalam periode tertentu (Aryantara, 2016). Indikator yang digunakan dalam mengukur kinerja keuangan perbankan termasuk lembaga keuangan seperti LPD adalah profitabilitas yakni kemampuan suatu perusahaan untuk menghasilkan laba selama periode tertentu (Setyawan, 2013).

Ke-enam Kecamatan yang ada di Kabupaten Badung. Kecamatan Abiansemal merupakan salah satu wilayah yang menjadi pusat pembangunan Badung Utara dan daerah dengan jumlah LPD terbanyak ke-dua di Kabupaten Badung, yaitu sebanyak 34 LPD dari 34 Desa Adat yang ada, sehingga rasio penyebaran LPD di Kecamatan Abiansemal yaitu 100\%.Berdasarkan data LPLPD Kabupaten Badung per Desember 2017 jumlah dana masyarakat yang terhimpun dalam LPD Se-Kecamatan Abiansemal sebesar Rp. 956.835.186 dengan jumlah nasabah sebanyak 16.979 orang nasabah. Dana tersebut diklasifikasikan menjadi 
dua macam, yaitu tabungan dan deposito. Berikut adalah data mengenai perkembangan dana LPD Se-Kecamatan Abiansemal Kabupaten Badung dilihat dalam Tabel 1.

Tabel 1.

Perkembangan Dana LPD Se-Kecamatan Abiansemal dari Tahun 2015-2017

\begin{tabular}{lccc}
\hline \multirow{2}{*}{ Uraian } & \multicolumn{3}{c}{ Tahun } \\
\cline { 2 - 4 } & Desember 2015 & Desember 2016 & Desember 2017 \\
\hline Tabungan & 303.538 .977 & 348.883 .469 & 389.780 .969 \\
Deposito & 355.613 .252 & 451.003 .759 & 558.054 .217 \\
Kredit & 573.068 .325 & 699.569 .849 & 808.051 .539 \\
\hline
\end{tabular}

Sumber: LPLPD Kabupaten Badung, 2018

Berdasarkan Tabel 1. diatas, dapat dilihat bahwa jumlahdana yang terhimpun dalam LPD Kecamatan Abiansemal setiap periodenya cenderung mengalami peningkatan. Hal tersebut mengindikasikan bahwa tingkat kepercayaan masyarakat terhadap LPD setiap periodenya semakin meningkat. Dibuktikan dengan meningkatnya keinginan masyarakat untuk menyimpan uangnya di LPD baik dalam bentuk tabungan maupun deposito.Tetapi walaupun kinerja keuangan LPD Se-Kecamatan Abiansemal secara umum dapat dikatakan baik, nyatanya masih terdapat LPD dengan klasifikasi kesehatan yang menurun dari tahun 2015 menuju 2017. LPD tidak sehat meningkat pada tahun 2017 seperti yang termuat dalam Tabel 2. dibawah ini 
Tabel 2.

Klasifikasi Kesehatan LPD Se-Kecamatan Abiansemal dari Tahun 2015-2017

\begin{tabular}{|c|c|c|c|c|}
\hline \multirow{2}{*}{\multicolumn{2}{|c|}{ Uraian }} & \multicolumn{3}{|c|}{ Tahun } \\
\hline & & Desember 2015 & Desember 2016 & Desember 2017 \\
\hline \multicolumn{5}{|c|}{ Klasifikasi Kesehatan } \\
\hline- & Sehat & 30 & 30 & 25 \\
\hline - & Cukup Sehat & 3 & 1 & 6 \\
\hline - & Kurang Sehat & 1 & 2 & 1 \\
\hline- & Tidak Sehat & 0 & 1 & 2 \\
\hline
\end{tabular}

Sumber: LPLPD Kabupaten Badung, 2018, 2018

Peran pengelola LPD sangat menentukan tingkat kesehatan LPD itu sendiri. Pengelolaan LPD yang terpisah dengan krama Desa tidak menutup kemungkinan adanya tindakan mementingkan diri sendiri di pihak pengelola LPD (agent) dan mengabaikan kepentingan krama Desa (principal) yang sering dikenal dengan konflik keagenan. Menurut Benhart dan Rosentein (1998) konflik yang timbul karena adanya persinggungan kepentingan antara pemilik dan manajemen dapat berdampak buruk bagi citra perusahaan serta kinerja yang dihasilkan perusahaan tersebut. Mengacu pada teori keagenan, peran pemilik perusahaan dalam hal penetapan intensif yang tepat bagi agent dan adanya pengalokasian biaya monitoring untuk agent akan membatasi pergerakan agent tersebut dalam hal melakukan tindakan - tindakan yang mementingkan dirinya sendiri. Menerapkan sistem tata kelola perusahaan yang baik (good corporate governance) juga sangat diperlukan untuk mengurangi terjadinya konflik keagenan. Menurut Oliver (1995), corporate governance muncul dalam organisasi disebabkan karena adanya masalah agensi atau konflik kepentingan yang melibatkan anggota organisasi.

Good Corporate Governance (GCG) merupakan suatu konsep tata kelola perusahaan yang menjelaskan hubungan antara pihak - pihak yang 
berkepentingan dengan perusahaan dalam upaya perbaikan kinerja perusahaan. Menurut Larcker (2007), corporate governance ditujukan pada mekanisme pengelolaan perusahaan terutama bagi manajer yang keputusannya akan dipertimbangkan untuk kepentingan dan tujuan perusahaan. Corporate governance semakin dipahami oleh kalangan pembuat kebijakan sebagai nilai untuk meningkatkan strategi bersaing perusahaan (Akinkoye \& Olasanmi, 2014)

Menerapkan sistem tata kelola yang baik pada organisasi sudah didukung dengan dikeluarkannya Pedoman Umum Good Corporate Governance Indonesia oleh Komite Nasional Kebijakan Governance (KNKG) pada tahun 2006. Terdapat unsur penting dalam pedoman tersebut yaitu adanya prinsip - prinsip GCG yang harus diterapkan perusahaan antara lain (1) Transparansi mengacu pada keterbukaan dalam proses pengambilan keputusan dan mengemukakan informasi. (2) Independensi, mengacu pada pengelolaan yang professional dan adanya objektivitas dalam setiap pengambilan keputusan tanpa ada intervensi dari pihak lain yang bertentangan dengan peraturan yang berlaku pada perusahaan. (3) Akuntabilitas, mengacu pada kejelasan pertanggungjawaban sesuai struktur perusahaan sehingga akan tercipta pengelolaan perusahaan yang efektif. (4) Responsibilitas, mengacu pada tanggungjawab untuk mematuhi peraturan perusahaan dan peraturan perundangan yang berlaku. (5) Kewajaran, yaitu tindakan yang adil dan setara dalam pemenuhan hak - hak dari para stakeholderssesuai dengan peraturan yang berlaku. Menurut Ferdiawan (2008) GCG merupakan salah satu faktor yang mendorong meningkatnya kinerja perusahaan karena adanya penerapan prinsip - prinsip GCG di perusahaan maka 
tingkat kepercayaan masyarakat akan meningkat. Berdasarkan hal tersebut, dengan menerapkan prinsip - prinsip GCG khususnya pada LPD diharapkan dapat memberikan manfaat pada pengelolaan LPD yang akan mengarah pada tingkat kesehatan yang lebih baik.

Transparansi adalah memberikan informasi secara terbuka dan jujur kepada stakeholders berdasarkan pertimbangan, bahkan stakeholders memiliki hak untuk mengetahui secara terbuka dan menyeluruh atas pertanggungjawaban perusahaan dalam pengelolaan sumber daya yang dipercayakan kepadanya. Berdasarkan hasil penelitian yang dilakukan oleh Sandraningsih dan Putri (2015), transparansi berpengaruh terhadap kinerja keuangan LPD di Kecamatan Abiansemal Kabupaten Badung. Hal tersebut juga terjadi pada penelitian Bulandari dan Damayanthi (2014) yang mendapatkan hasil bahwa transparansi memiliki pengaruh terhadap kinerja keuangan LPD di Kabupaten Badung. Keterbukaan dalam pengungkapan informasi mengenai perusahaan akan meningkatkan kepercayaan stakeholders terhadap perusahaan, sehingga tingkat kesehatan perusahaan diharapkan akan menjadi lebih baik. Berdasarkan uraian tersebut maka rumusan hipotesis pertama dalam penelitian ini adalah:

$\mathrm{H}_{1}$ : Transparansi berpengaruh positif pada tingkat kesehatan LPD

Akuntabilitas adalah kejelasan dari fungsi, struktur, sistem, pelaksanaan, dan pertanggung jawaban sehingga perusahaan dapat dikelola secara efektif. Oleh sebab itu perusahaan mesti dikelola secara benar, terukur, serta sesuai dengan kepentingan perusahaan dengan tetap mempertimbangkan kepentingan dari stakeholder (Putri dan Ulupui, 2017:36). Berdasarkan penelitian yang dilakukan 
oleh Dewi dan Putri (2014), prinsip akuntabilitas memiliki pengaruh positif pada kinerja keuangan LPD Kabupaten Gianyar. Hal tersebut sejalan dengan hasil penelitian yang dilakukan oleh Baskara dan Erawati (2017) yang mendapat hasil bahwa akuntabilitas berpengaruh positif pada kinerja keuangan LPD. Sesuai dengan agency theory, hal ini menunjukkan bahwa semakin jelas wewenang dan fungsi pelaksanaan serta pertanggungjawaban struktur organisasi dalam LPD maka pengelolaan LPD akan terlaksana secara efektif dan meningkatkan kepercayaan prinsipal sehingga pada akhirnya meningkatkan tingkat kesehatan LPD. Berdasarkan uraian tersebut maka rumusan hipotesis kedua dalam penelitian ini adalah:

$\mathrm{H}_{2}$ : Akuntabilitas berpengaruh positif pada tingkat kesehatan LPD

Responsibilitas adalah sikap perusahaan dalam mengelola usahanya berdasarkan peraturan perundang-undangan yang berlaku. Untuk meningkatkan kinerjanya, perusahaan harus memahami dan mematuhi peraturan serta melaksanakan tanggung jawab terhadap masyarakat sehingga dapat terpelihara kesinambungan usaha dalam jangka panjang dan mendapat pengakuan sebagai good corporate citizen (Putri dan Ulupui, 2017:39). Penelitian ini yang dilakukan oleh Hindistari dan Putri (2016) mendapatkan hasil bahwa responsibilitas memiliki pengaruh positif pada kinerja Bank Perkreditan Rakyat (BPR) di Kabupaten Gianyar. Begitupula dengan penelitian yang dilakukan oleh Sandraningsih dan Putri (2015) mendapatkan hasil yaitu responsibilitas memliki pengaruh positif terhadap kinerja keuangan LPD di Kecamatan Abiansemal Kabupaten Badung. Sesuai dengan agency theory, hal ini menunjukkan bahwa 
dengan mematuhi segala peraturan yang ada serta melaksanakan tanggung jawab terhadap prinsipal dapat memberi dampak pada pertumbuhan LPD yang berdampak pada meningkatnya tingkat kesehatan LPD. Berdasarkan uraian tersebut maka rumusan hipotesis ketiga dalam penelitian ini adalah:

$\mathrm{H}_{3}$ : Responsibilitas berpengaruh positif pada tingkat kesehatan LPD

Independensi adalah sikap perusahaan dalam mengambil keputusan tanpa terikat dengan pihak manapun atau pihak yang mendominasi. Untuk meningkatkan kinerjanya, perusahaan harus bersikap secara objektif atau bebas dari kepentingan pihak yang merugikan perusahaan. Penelitian ini dilakukan oleh Bulandari dan Damayanthi (2014) mendapatkan hasil bahwa independensi memiliki pengaruh positif terhadap kinerja keuangan LPD Kabupaten Badung. Hal serupa juga ditemukan dalam penelitian Sandraningsih dan Putri (2015) yang mendapatkan hasil bahwa independensi memiliki pengaruh positif terhadap kinerja keuangan LPD di Kecamatan Abiansemal Kabupaten Badung. Sesuai dengan agency theory, hal ini menunjukkan dengan tidak adanya benturan kepentingan dalam pengelolaan LPD dapat berdampak pada meningkatnya kepercayaan prinsipal serta tingkat kesehatan LPD dan memastikan bahwa LPD telah bersikap objektif dalam pengelolaanya. Berdasarkan uraian tersebut maka rumusan hipotesis keempat dalam penelitian ini adalah:

$\mathrm{H}_{4}$ : Independensi berpengaruh positif pada Tingkat Kesehatan LPD

Kewajaran adalah keadilan dan kesetaraan perusahaan dalam memenuhi kepentingan stakeholders yang timbul berdasarkan perjanjian dan peraturan perundang-undangan yang berlaku. Perusahaan harus senantiasa memperhatikan 
hak-hak para pemangku kepentingan berdasarkan asas kewajaran dan kesetaraan dalam rangka meningkatkan tingkat kesehatan perusahaan ke arah yang lebih baik. Berdasarkan penelilitan Dewi dan Putri (2014) menyatakan bahwa kewajaran memiliki pengaruh positif terhadap kinerja keuangan LPD di Kabupaten Gianyar. Hal tersebut sejalan dengan penelitian yang dilakukan Hindistari dan Putri (2016) yang mendapatkan hasil bahwa prinsip kewajaran berpengaruh positif pada kinerja Bank Perkreditan Rakyat Kabupaten Gianyar. Sesuai dengan agency theory, hal ini menunjukkan apabila pengelolaan LPD memperhatikan hak dari prinsipal serta memperlakukannya secara adil berdasarkan asas kewajaran dan kesetaraan maka dapat meningkatkan tingkat kesehatan LPD. Berdasarkan uraian tersebut maka rumusan hipotesis kelima dalam penelitian ini adalah:

H5 : Kewajaran berpengaruh positif pada Tingkat Kesehatan LPD

\section{METODE PENELITIAN}

Penelitian ini menggunakan pendekatan kuantitatif yang berbentuk asosiatif. Menggunakan pendekatan kuantitaif karena data yang digunakan merupakan hasil scoring data kualitatif. Berbentuk asosiatif karena penelitian ini bertujuan untuk mengetahui hubungan atau pengaruh antara dua variabel atau lebih (Sugiyono, 2006:11). Hubungan antara variabel independen dan variabel dependen ini dapat digambarkan pada Gambar 1. 


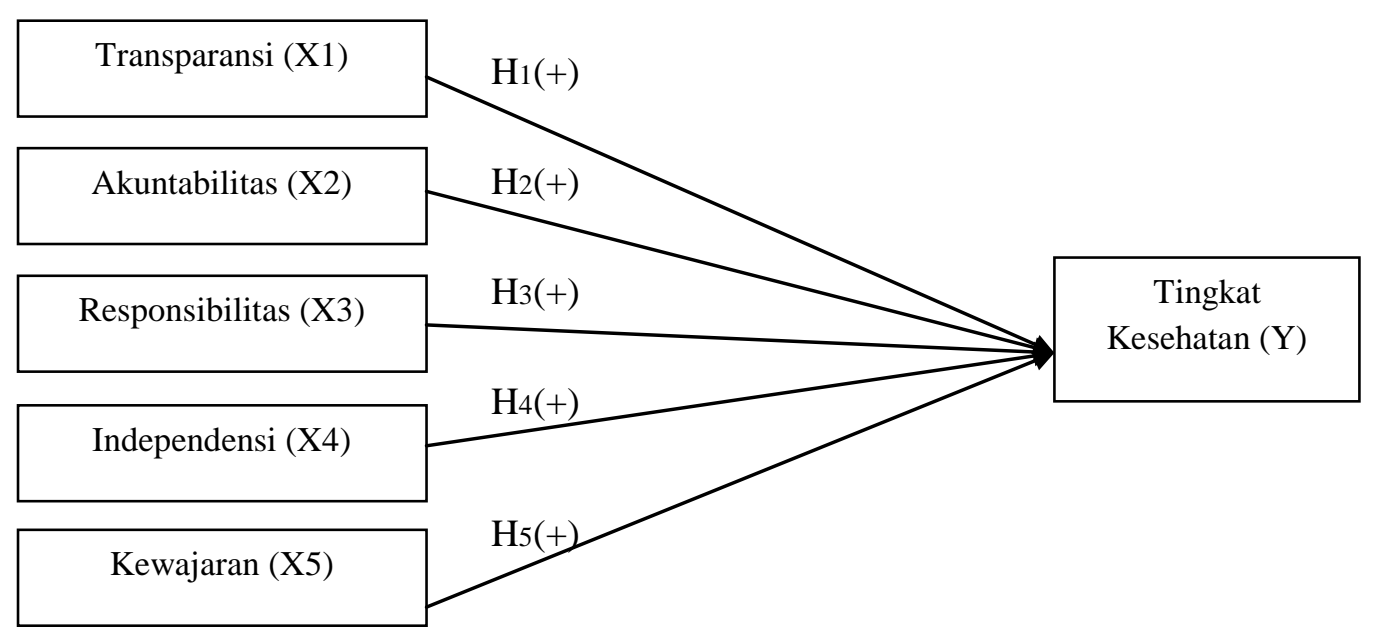

Gambar 1. Kerangka Konseptual Penelitian

Lokasi penelitian dilakukan pada seluruh LPD yang berada di Kecamatan Abiansemal, Kabupaten Badung. Kecamatan Abiansemal dipilih karena merupakan salah satu wilayah yang menjadi pusat pembangunan Badung Utara dan merupakan daerah yang masih mempunyai potensi dalam bidang pertanian, industri kecil dan rumah tangga yang sangat memberikan dampak pada perekonomian masyarakat. Sedangkan obyek dalam penelitian ini adalah prinsipprinsip good governance yang terdiri dari lima prinsip, yaitu transparansi, akuntabilitas, responsibilitas, independensi, kewajaran pada tingkat kesehatan LPD Se-Kecamatan Abiansemal Kabupaten Badung.

Variabel bebas dalam penelitian ini adalah transparansi $\left(\mathrm{X}_{1}\right)$, akuntabilitas $\left(\mathrm{X}_{2}\right)$, responsibilitas $\left(\mathrm{X}_{3}\right)$, independensi $\left(\mathrm{X}_{4}\right)$, kewajaran $\left(\mathrm{X}_{5}\right)$. Sedangkan variabel terikat dalam penelitian ini adalah tingkat kesehatan yang diukur dengan skor tingkat kesehatan LPD. Nilai Kesehatan LPD pada LPLPD Kabupaten Badung 
yang pada penelitian ini diukur menggunakan score skala 1-4 disajikan seperti berikut:

Tabel 3.

Nilai Kesehatan LPD

\begin{tabular}{ccc}
\hline Total Nilai Kesehatan & Kriteria & Score \\
\hline $81-100$ & Sehat & 4 \\
$66-81$ & Cukup Sehat & 3 \\
$51-66$ & Kurang Sehat & 2 \\
$0-51$ & Tidak Sehat & 1 \\
\hline
\end{tabular}

Sumber: LPLPD Kabupaten Badung, 2018

Jenis data yang digunakan dalam penelitian ini adalah data kuantitatif meliputi nilai atau skor atas jawaban yang diberikan oleh responden terhadap pernyataan-pernyataan yang ada dalam kuisioner penelitian serta jumlah LPD yang diperoleh dari LPLPD Kabupaten Badung. Data kualitatif berupa daftar nama LPD yang berada di Kecamatan Abiansemal Kabupaten Badung yang diperoleh dari LPLPD Kabupaten Badung. Sedangkan sumber data yang digunakan dalam penelitian ini adalah sumber primer berupa hasil jawaban responden yang diperoleh secara langsung melalui kuisioner yang dibagikan pada setiap responden penelitian. Sumber sekunder berupa laporan keuangan LPD SeKecamatan Abiansemal yang diperoleh dari LPLPD Kabupaten Badung.

Populasi dalam penelitian ini adalah seluruh Lembaga Perkreditan Desa (LPD) yang berada di Kecamatan Abiansemal Kabupaten Badung. Wilayah ini dipilih karena dari 34 Desa Adat yang ada di Kecamatan Abiansemal, seluruhnya telah memiliki LPD dan merupakan wilayah dengan jumlah LPD terbanyak ke-2 yang ada di Kabupaten Badung. Pengambilan sampel menggunakan teknik nonprobability sampling yang meliputi sampling jenuh, dimana dalam teknik ini 
semua anggota populasi digunakan sebagai sampel. Sehingga didapat jumlah sampel penelitian yaitu 34 sampel dengan masing - masing ketua LPD sebagai responden penelitian.

Metode pengumpulan data yang digunakan dalam penelitian ini adalah kuisioner berupa daftar pernyataan yang berkaitan dengan variabel-variabel yang akan diteliti. Wawancara tidak terstruktur dilakukan dengan kepala LPLPD Kabupaten Badung untuk mendapatkan informasi berkaitan dengan LPD. Dokumentasi berupa data mengenai laporan keuangan Lembaga Perkreditan Desa di Kecamatan Abiansemal.

Teknik analisis data yang digunakan dalam penelitian ini adalah teknik analisis regresi linier berganda Sebelum melakukan pengujian regresi, terdapat beberapa asumsi yang harus dipenuhi agar data yang akan dimasukkan dalam model regresi telah memenuhi ketentuan dan syarat dalam regresi. Uji asumsi klasik dalam penelitian ini mencakup uji normalitas, multikolinearitas, dan heteroskedastisitas. Model regresi linier berganda dirumuskan sebagai berikut.

$Y=\alpha+\beta_{1} X_{1}+\beta_{2} X_{2}+\beta_{3} X_{3}+\beta_{4} X_{4}+\beta_{5} X_{5}+\varepsilon$

Keterangan :

$\begin{array}{ll}\mathrm{Y} & =\text { Tingkat Kesehatan LPD } \\ \mathrm{A} & =\text { Konstanta } \\ \beta_{1} \beta_{2} \beta_{3} \beta_{4} \beta_{5} \beta_{6} & =\text { Koefisien Regresi } \\ \mathrm{X}_{1} & =\text { Transparansi } \\ \mathrm{X}_{2} & =\text { Akuntabilitas } \\ \mathrm{X}_{3} & =\text { Responsibilitas } \\ \mathrm{X}_{4} & =\text { Independensi } \\ \mathrm{X}_{5} & =\text { Kewajaran } \\ \varepsilon & =\text { Error Term }\end{array}$




\section{HASIL DAN PEMBAHASAN}

Penelitian ini responden penelitian dibagi ke dalam beberapa karakteristik, mulai dari jenis kelamin, usia serta tingkat pendidikan. Berikut merupakan data mengenai karakteristik responden penelitian yang termuat dalam Tabel 4 .

Tabel 4.

Karakteristik Responden Penelitian

\begin{tabular}{ccc}
\hline \multicolumn{1}{c}{ Keterangan } & Jumlah & Persentase (\%) \\
\hline Jenis Kelamin & & \\
\multicolumn{1}{c}{ Laki-laki } & 23 & $68 \%$ \\
Perempuan & 11 & $32 \%$ \\
Jumlah & 34 & $100 \%$ \\
& & \\
21-30 tahun & 1 & $3 \%$ \\
31-40 tahun & 5 & $15 \%$ \\
41-50 tahun & 18 & $53 \%$ \\
51-60 tahun & 10 & $29 \%$ \\
$>60$ tahun & 0 & $0 \%$ \\
Jumlah & 34 & $100 \%$ \\
Pendidikan Terakhir & & \\
SMA/SMK & 19 & $56 \%$ \\
Diploma & 3 & $9 \%$ \\
Sarjana & 12 & $35 \%$ \\
Pasca Sarjana & 0 & $29 \%$ \\
Jumlah & 34 & $100 \%$ \\
\hline
\end{tabular}

Sumber: Data Diolah, 2018

Berdasarkan Tabel 4. di atas, dapat dijelaskan uraian karakteristik responden dalam penelitian ini. Jenis kelamin digunakan untuk mengetahui proporsi responden laki-laki dan perempuan pada LPD se-Kecamatan Abiansemal. Responden yang berjenis kelamin laki-laki berjumlah 23 orang $(68 \%)$ dan responden yang berjenis kelamin wanita sebanyak 11 orang (32\%). Usia digunakan untuk mengetahui rentang usia responden penelitian pada LPD seKecamatan Abiansemal. Sebanyak 1 orang responden dengan usia 21-30 tahun, 5 orang dengan usia 31-40 tahun, 19 orang dengan usia 41-50 tahun, 10 orang usia 
Ni Made Madani Hapsari dan I Dewa Nyoman Wiratmaja. Pengaruh ...

51-60 tahun serta tidak ada responden yang usianya $>60$ tahun. Tingkat pendidikan digunakan untuk mengetahui pendidikan terakhir responden penelitian yang ada di LPD se-Kecamatan Abiansemal. Sebanyak 19 orang pendidikan terakhirnya SMA/SMK, 3 orang pendidikan terakhirnya Diploma, dan 12 orang pendidikan terakhirnya sarjana serta tidak ada responden yang pendidikan terakhirnya pasca sarjana.

Suatu instrumen yang valid ditunjukkan dengan $\mathrm{r}$ Pearson Correlation $\geq$ 0,30. Pada Tabel 2. menunjukkan bahwa seluruh variabel memiliki nilai koefisien korelasi dengan skor total seluruh item pernyataan lebih besar dari 0,30 . Hal ini menunjukkan butir-butir pernyataan dalam instrumen penelitian tersebut valid.

Tabel 5.

Hasil Uji Validitas

\begin{tabular}{|c|c|c|c|c|c|}
\hline No & Variabel & Indikator & Nilai Correlation & Signifikansi & Keterangan \\
\hline \multirow[t]{3}{*}{1} & Transparansi & $\mathrm{X} 1.1$ & 0,859 & 0,000 & Valid \\
\hline & & $\mathrm{X} 1.2$ & 0,856 & 0,000 & Valid \\
\hline & & $\mathrm{X} 1.3$ & 0,959 & 0,000 & Valid \\
\hline \multirow[t]{3}{*}{2} & Akuntabilitas & $\mathrm{X} 2.1$ & 0,870 & 0,000 & Valid \\
\hline & & $\mathrm{X} 2.2$ & 0,924 & 0,000 & Valid \\
\hline & & $\mathrm{X} 2.3$ & 0,865 & 0,000 & Valid \\
\hline \multirow[t]{3}{*}{3} & Responsibilitas & X3.1 & 0,851 & 0,000 & Valid \\
\hline & & $\mathrm{X} 3.2$ & 0,774 & 0,000 & Valid \\
\hline & & X3.3 & 0,884 & 0,000 & Valid \\
\hline \multirow[t]{2}{*}{4} & Indenpendensi & $\mathrm{X} 4.1$ & 0,926 & 0,000 & Valid \\
\hline & & $\mathrm{X} 4.2$ & 0,891 & 0,000 & Valid \\
\hline \multirow[t]{3}{*}{5} & Kewajaran & X5.1 & 0,898 & 0,000 & Valid \\
\hline & & $\mathrm{X} 5.2$ & 0,827 & 0,000 & Valid \\
\hline & & X5.3 & 0,934 & 0,000 & Valid \\
\hline
\end{tabular}

Sumber: Data diolah, 2018

Hasil uji validitas pada Tabel 5. diperoleh nilai correlation total pada masing-masing indikator memiliki nilai signifikansi $0,000<0,05$, sehingga 
instrumen penelitian pada masing-masing variabel dapat digunakan sebagai alat pengumpulan data karena telah memenuhi kriteria validitas.

Uji reliabilitas mampu menunjukan sejauh mana instrument dapat dipercaya dan diharapkan. Nilai suatu instrument dikatakan reliable apabila nilai Alpha Cronbach 1 0,60. Hasil uji reliabilitas dapat dilihat pada Tabel 6.

Tabel 6.

Hasil Uji Reliabilitas

\begin{tabular}{clcc}
\hline No & Variabel & Alpha Cronbach's & Keterangan \\
\hline 1 & Transparansi & 0,872 & Reliabel \\
2 & Akuntabilitas & 0,864 & Reliabel \\
3 & Responsibilitas & 0,787 & Reliabel \\
4 & Indenpendensi & 0,783 & Reliabel \\
5 & Kewajaran & 0,863 & Reliabel \\
\hline
\end{tabular}

Sumber: Data diolah, 2018

Berdasarkan Tabel 6. menunjukkan bahwa nilai Cronbach's Alpha masingmasing variabel lebih besar dari 0,60 yang artinya bahwa seluruh pernyataan dalam kuesioner penelitian ini reliabel dan dapat digunakan.

Uji normalitas menggunakan uji Kolmogorov-Smirnov, dengan uji ini dapat diketahui data yang digunakan berdistribusi normal atau tidak. Apabila Sign t hitung $>0.05$, maka data tersebut berdistribusi normal dan begitu juga sebaliknya (Santoso, 2001).

Tabel 7.

Hasil Uji Normalitas

\begin{tabular}{llr}
\hline & & Unstandardized Residual \\
\hline $\mathrm{N}$ & & 34 \\
Normal Parameters $^{\mathrm{a}, \mathrm{b}}$ & Mean &, 0000000 \\
& Std. Deviation &, 72020740 \\
Most Extreme Differences & Absolute &, 181 \\
& Positive &, 144 \\
& Negative &,- 181 \\
Test Statistic & &, 114 \\
Asymp. Sig. (2-tailed) & &, $061^{\mathrm{c}}$ \\
\hline Sumber: Data diolah, 2018 & &
\end{tabular}


Hasil Pengujian Kolmogrov-Smirnov pada Tabel 7. menunjukkan bahwa nilai signifikansi untuk persamaan model regresi adalah 0,061 >0,05. Hal ini menunjukkan bahwa persamaan regresi dalam model penelitian ini memiliki sebaran data yang normal.

Uji multikolinieritas digunakan untuk mengetahui apakah antara variabel bebas terjadi multikolinieritas atau tidak. Uji yang digunakan yaitu dengan melihat nilai VIF (Varian Inflation Factor) dan Tolerance pada proses regresi biasa, jika keduanya mendekati 1 atau besaran VIF kurang dari 10 maka model tidak terkena multikolinieritas. Berdasasrkan hasil pengujian multikolinearitas dapat diperoleh hasil sebagai berikut.

Tabel 8.

Hasil Uji Multikolinearitas

\begin{tabular}{rlcc}
\hline No & \multicolumn{1}{c}{ Variabel } & Tolerance & VIF \\
\hline 1 & Transparansi & 0,424 & 2,358 \\
2 & Akuntabilitas & 0,409 & 2,446 \\
3 & Responsibilitas & 0,847 & 1,181 \\
4 & Indenpendensi & 0,586 & 1,705 \\
5 & Kewajaran & 0,673 & 1,487 \\
\hline
\end{tabular}

Sumber: Data diolah, 2018

Hasil regresi pada Tabel 8. menunjukkan bahwa nilai tolerance pada masing-masing variabel lebih besar dari $10 \%(0,1)$, demikian pula dengan nilai VIF masing-masing variabel yang lebih kecil dari 10. Dengan demikian dapat disimpulkan antara variabel bebas dalam penelitian ini tidak terjadi multikolinearitas.

Uji Heteroskedastisitas bertujuan untuk menguji apakah dalam model terjadi ketidaksamaan varian atau residual satu pengamatan ke pengamatan lainnya. Jika tingkat signifikan lebih besar dari 0,05 maka terjadi heteroskedastisitas. 
Tabel 9.

Hasil Uji Heteroskedastisitas

\begin{tabular}{|c|c|c|c|c|c|c|}
\hline & \multirow[t]{2}{*}{ Model } & \multicolumn{2}{|c|}{$\begin{array}{c}\text { Unstandardized } \\
\text { Coefficients }\end{array}$} & \multirow{2}{*}{$\begin{array}{c}\begin{array}{c}\text { Standardized } \\
\text { Coefficients }\end{array} \\
\text { Beta }\end{array}$} & \multirow[t]{2}{*}{$t$} & \multirow[t]{2}{*}{ Sig. } \\
\hline & & $B$ & Std. Error & & & \\
\hline \multirow[t]{6}{*}{1} & (Constant) & ,457 & ,089 & & 5,124 & ,000 \\
\hline & $\mathrm{X} 1$ & ,099 &, 125 & , 177 & ,792 & ,435 \\
\hline & $\mathrm{X} 2$ & ,068 &, 115 & 116 & ,594 &, 558 \\
\hline & X3 &,- 054 & ,047 &,- 242 & $-1,169$ &, 252 \\
\hline & $\mathrm{X} 4$ &, 150 & , 157 & 234 & ,958 & ,346 \\
\hline & $\mathrm{X} 5$ &,- 096 &, 114 &,- 194 &,- 837 & ,409 \\
\hline
\end{tabular}

Sumber: Data diolah, 2018

Tabel 9. menunjukkan bahwa seluruh variabel memiliki nilai signifikan lebih besar dari 0,05 sehingga model regresi pada penelitian ini tidak mengandung gejala heteroskedastisitas.

Tabel 10.

Hasil Uji Regresi Linier Berganda

\begin{tabular}{ccccccc}
\hline \multirow{2}{*}{ Model } & \multicolumn{2}{c}{$\begin{array}{c}\text { Unstandardized } \\
\text { Coefficients }\end{array}$} & $\begin{array}{c}\text { Standardized } \\
\text { Coefficients }\end{array}$ & \multirow{2}{*}{$\boldsymbol{t}$} & \multirow{2}{*}{ Sig. } \\
\cline { 3 - 5 } & & $\boldsymbol{B}$ & Std. Error & Beta & & \\
\hline 1 & (Constant) & 1,112 &, 633 & & 1,755 &, 090 \\
& X1 &, 151 &, 064 &, 490 & 2,350 &, 026 \\
X2 &, 066 &, 066 &, 211 &, 995 &, 328 \\
& X3 &, 068 &, 048 &, 206 & 1,398 &, 173 \\
& X4 &,- 052 &, 081 &,- 115 &,- 648 &, 522 \\
& X5 &, 006 &, 051 &, 019 &, 113 &, 911 \\
\hline
\end{tabular}

Sumber: Data diolah, 2018

Sesuai dengan hasil perhitungan dengan menggunakan program SPSS for windows maka diperoleh hasil analisis regresi linear berganda. Dari Tabel 10. dapat disusun persamaan regresi linear berganda yaitu:

$Y=1,112+0,151 X_{1}+0,066 X_{2}+0,068 X_{3}+-0,052 X_{4}+0,006 X_{5}$

Berdasarkan persamaan regresi diperoleh nilai konstanta sebesar 1,112 artinya apabila variabel transparansi, akuntabilitas, responsibilitas, independensi, 
dan kewajaran tidak mengalami perubahan atau sama dengan konstan, maka tingkat kesehatan pada LPD di Abiansemal sebesar 1,112.

Berdasarkan Tabel 10. menunjukkan bahwa koefisien determinasi yaitu nilai adjusted $R^{2}$ adalah 0,392 atau 39,2\% artinya kontribusi variabel transparansi, akuntabilitas, responsibilitas, independensi, dan kewajaran terhadap tingkat kesehatan LPD di Kecamatan Abiansemal sebesar 39,2\% sedangkan sisanya $60,8 \%$ dipengaruhi oleh variabel lain yang tidak termasuk dalam model penelitian. Uji kelayakan model bertujuan untuk mengetahui apakah model regresi yang digunakan dalam penelitian ini layak atau tidak digunakan sebagai alat analisis untuk menguji pengaruh variabel bebas pada variabel terikatnya. Hasil uji kelayakan model ditunjukkan pada Tabel 11. sebagai berikut.

Tabel 11.

Hasil Uji Kelayakan Model

\begin{tabular}{ccccccc}
\hline & Model & Sum of Squares & Df & Mean Square & F & Sig. \\
\hline 1 & Regression & 10,897 & 5 & 2,179 & 5,259 &, $002^{\mathrm{b}}$ \\
& Residual & 11,603 & 28 &, 414 & & \\
& Total & 22,500 & 33 & & & \\
\hline
\end{tabular}

Sumber: Data diolah, 2018

Berdasarkan hasil uji kelayakan modal pada Tabel 11. diperoleh nilai $F$ hitung sebesar 5,259 dengan tingkat signifikansi $0,002<0,05$ artinya variabel transparansi, akuntabilitas, responsibilitas, independensi, dan kewajaran mampu menjelaskan tingkat kesehatan pada LPD di Kecamatan Abiansemal dan telah memenuhi syarat goodness of fit.

Uji hipotesis bertujuan untuk mengetahui apakah masing-masing variabel independen mempunyai pengaruh secara signifikan pada variabel dependennya. Level of significant yang digunakan adalah 0,05 (5\%). Apabila probabilitas 
signifikansi lebih kecil dari 0,05 maka H0 ditolak dan H1 diterima. Berdasarkan Tabel 10. maka hasil pengujian secara parsial masing-masing variabel independen terhadap dependen dapat dijabarkan sebagai berikut. Berdasarkan hasil pengujian hipotesis diperoleh nilai t hitung sebesar 2,350 dengan tingkat signifikansi 0,026 < 0,05. Hal ini menunjukkan bahwa variabel transparansi berpengaruh positif signifikan pada tingkat kesehatan LPD di Kecamatan Abiansemal. Hal ini mengindikasikan bahwa peningkatan transparansi akan meningkatkan tingkat kesehatan LPD di Kecamatan Abiansemal.

Penelitian untuk menguji pengaruh transparansi pada tingkat kesehatan LPD belum banyak dilakukan. Akan tetapi pengujian pengaruh transparansi pada kinerja keuangan telah dilakukan oleh Wirajaya dan Oka serta Erawati dan Baskara, kinerja keuangan yang telah diteliti sebelumnya memiliki kemiripan dengan tingkat kesehatan LPD, dimana tingkat kesehatan LPD sangat ditentukan oleh kinerja keuangan, perbedaannya adalah tingkat kesehatan LPD juga mempertimbangkan aspek manajemen. Hasil penelitian ini sejalan dengan penelitian yang dilakukan oleh Wirajaya dan Oka (2018) yang menemukan bahwa transparansi berpengaruh positif pada kinerja keuangan LPD di Klungkung. Temuan ini juga sejalan dengan hasil penelitian Erawati dan Bhaskara (2017) yang menemukan bahwa transparansi berpengaruh signifikan pada kinerja keuangan LPD di Kecamatan Abiansemal.

Temuan penelitian ini menunjukkan bahwa transparansi berpengaruh positif pada tingkat kesehatan LPD di Kecamatan Abiansemal, ini berarti apabila manajemen dalam pengelolaan LPD menerapkan prinsip transparansi seperti 
menyajikan laporan keuangan secara terbuka, proses pengambilan keputusan yang transparan melalui rapat, dan adanya keterbukaan mengenai informasi maka akan mampu meningkatkan tingkat kesehatan LPD.

Hasil pengujian hipotesis diperoleh nilai t hitung sebesar 0,995 dengan tingkat signifikansi $0,328>0,05$. Hal ini menunjukkan bahwa variabel akuntabilitas berpengaruh secara tidak signifikan pada tingkat kesehatan LPD di Kecamatan Abiansemal. Hal ini mengindikasikan bahwa peningkatan atau penurunan akuntabilitas tidak berdampak pada tingkat kesehatan LPD. Tidak berpengaruhnya akuntabilitas disaat transaparansi berpengaruh positif pada tingkat kesehatan LPD mengindikasikan bahwa manajemen LPD lebih fokus dan mengedepankan penerapan prinsip-prinsip transparansi. Saat manajemen LPD terdorong untuk memberikan informasi secara transparan maka mereka harus memastikan akuntabilitas operasi pada LPDnya.

Hasil penelitian ini tidak sejalan dengan penelitian yang dilakukan oleh Asri dan Khrisna (2017) yang menemukan bahwa akuntabilitas memiliki pengaruh yang positif pada kinerja keuangan LPD di Kota Denpasar. Hal ini juga tidak sejalan dengan penelitianDamayanthi dan Bulandari (2014) yang menemukan bahwa akuntabilitas positif dan berpengaruh signifikan pada kinerja LPD di Kabupaten Badung. Perbedaan temuan penelitian ini kemungkinan disebabkan oleh perbedaan pada responden dan lokasi penelitian.

Akuntabilitas tidak berpengaruh pada tingkat kesehatan LPD karena dalam penelitian ini mungkin akuntabilitas dipersepsikan telah melekat pada aspek transparansi. Disaat pengurus LPD telah menyajikan informasi secara periodik 
melalui pelaksanaan pembuatan Laporan Keuangan Bulanan, mereka menganggap bahwa penyajian informasi tersebut telah mewakili penerapan prinsip akuntabilitas. Hasil pengujian hipotesis diperoleh nilai t hitung sebesar 1,398 dengan tingkat signifikansi 0,173 >0,05. Hal ini menunjukkan bahwa variabel responsibilitas berpengaruh secara tidak signifikan pada tingkat kesehatan LPD di Kecamatan Abiansemal. Hal ini mengindikasikan bahwa peningkatan responsibilitas tidak berdampak pada tingkat kesehatan LPD. Tidak berpengaruhnya responsibilitas disaat transaparansi berpengaruh positif pada tingkat kesehatan LPD mengindikasikan bahwa manajemen LPD pada saat memberikan informasi secara transparan maka mereka harus memastikan responsibilitas pada laporan yang disajikan oleh LPD.

Hasil penelitian ini sejalan dengan penelitian yang dilakukan oleh Asri dan Khrisna (2017) yang menemukan bahwa responsibilitas berpengaruh tidak signifikan pada kinerja keuangan LPD di Kota Denpasar.Temuan ini sejalan dengan hasil penelitian Erawati dan Bhaskara (2017) yang menemukan bahwa responsibiltas berpengaruh tidak signifikan pada kinerja keuangan LPD di Kecamatan Abiansemal.

Hal ini dimungkinkan terjadi karena penerapan prinsip responsibilitas dalam pandangan manajemen LPD telah melekat pada penerapan prinsip transparansi disaat manajemen LPD telah taat dan patuh terhadap seluruh peraturan yang berlaku, maka dianggap sudah secara langsung melekat pada prinsip transparansi yang diterapkan oleh manajemen LPD. Kepatuhan terhadap seluruh peraturan yang berlaku dalam pandangan manajemen LPD melekat pada penerapan prinsip 
transparansi disaat mereka dituntut untuk transparan maka secara langsung mereka wajib untuk mematuhi peraturan yang berlaku.

Hasil pengujian hipotesis diperoleh nilai t hitung sebesar -0,648 dengan tingkat signifikansi $0,522>0,05$. Hal ini menunjukkan bahwa variabel independensi berpengaruh secara tidak signifikan pada tingkat kesehatan LPD di Kecamatan Abiansemal. Hal ini menunjukkan bahwa apabila manajemen LPD bertindak secara independensi, mungkin manajemen LPD akan bertindak diluar kendali oleh dewan pengawas atau krama Desa.

Hal ini juga didukung oleh penelitian Erawati dan Bhaskara (2017) yang menemukan bahwa independensi negatif dan tidak berpengaruh signifikan pada kinerja keuangan LPD. Namun temuan ini tidak sejalan dengan penelitian Asri dan Khrisna (2017) yang menemukan bahwa independensi berpengaruh positif terhadap kinerja keuangan LPD di Kota Denpasar. Perbedaan temuan penelitian ini kemungkinan disebabkan oleh perbedaan pada responden dan lokasi penelitian. Hal ini dimungkinkan terjadi karena dalam proses pengambilan keputusan, peran dari Dewan Pengawas sangat penting. Independensi dalam pengambilan keputusan oleh ketua LPD, menerapkan suatu keharusan bagi mereka disaat mereka merasa wajib untuk menerapkan prinsip-prinsip transparansi. Disaat ada tuntutan untuk mengumpulkan informasi secara terbuka maka ketua LPD secara langsung merasa wajib untuk menerapkan prinsip independensi.

Hasil pengujian diperoleh nilai $\mathrm{t}$ hitung sebesar 0,113 dengan tingkat signifikansi $0,911>0,05$. Hal ini menunjukkan bahwa variabel kewajaran 
berpengaruh secara tidak signifikan pada tingkat kesehatan LPD di Kecamatan Abiansemal. Hal ini menunjukkan bahwa manajemen LPD sudah secara terbuka pada saat manajemen LPD melaporkan informasi mengenai LPD kepada krama Desa secara transparan dan terbuka. Secara tidak langsung manajemen LPD akan menerapkan prinsip transparansi yang mengandung unsur kewajaran dimana krama Desa pada saat itu bebas untuk memberikan masukan dan pendapat.

Hal ini juga didukung oleh penelitian Erawati dan Bhaskara (2017) yang menemukan bahwa independensi negatif dan tidak berpengaruh signifikan pada kinerja keuangan Lembaga Perkreditan Desa (LPD). Namun penelitian ini tidak sejalan dengan Asri dan Khrisna (2017) yang menemukan bahwa kewajaran berpengaruh positif pada kinerja keuangan LPD di Kota Denpasar. Perbedaan temuan penelitian ini kemungkinan disebabkan oleh perbedaan responden dan lokasi penelitian.

Kewajaran tidak berpengaruh pada tingkat kesehatan LPD karena dalam penelitian ini mungkin kewajaran dipersepsikan telah melekat pada aspek transparansi. Hal ini dapat memberikan informasi kepada seluruh anggota dan apabila terjadi kesalahan Dewan Pengawas atau krama Desa dapat bebas memberikan saran dan pendapat untuk meningkatkan tingkat kesehatan LPD.

\section{SIMPULAN}

Berdasarkan pembahasan hasil penelitian di atas, dapat disimpulkan bahwa penerapan prinsip transparansi berpengaruh signifikan terhadap tingkat kesehatan LPD. Sementara itu prinsip akuntabilitas, responsibilitas, independensi dan kewajaran tidak berpengaruh terhadap tingkat kesehatan LPD. Sedangkan saran 
Ni Made Madani Hapsari dan I Dewa Nyoman Wiratmaja. Pengaruh ...

yang dapat diberikan adalah sebaiknya LPD se-Kecamatan Abiansemal selalu menjaga dan meningkatkan mutu penerapan prinsip transparansi. Namun ada baiknya prinsip-prinsip lain seperti akuntabilitas, responsibilitas, independensi, dan kewajaran perlu ditingkatkan penerapannya agar tercipta keseimbangan penerapan prinsip-prinsip Good Corporate Governance sehingga dapat meningkatkan tingkat kesehatan LPD. Sosialisasi tentang prinsip-prinsip Good Corporate Governance perlu dikembangkan kepada seluruh karyawan LPD, agar mudah dipahami sehingga LPD dapat lebih mudah dalam pencapaian tujuannya.

\section{REFERENSI}

Akinkoye, E. Y., \& Olasanmi, O. O. 2014. Corporate governance practice and level of compliance among firms in Nigeria: Industry analysis. Journal of Business and Retail Management, 9(1).

Aryantara, G. 2016. Pengaruh Implementasi Prinsip - prinsip Good Corporate Governance dan Pengawasan LPD di Kabupaten Klungkung.Skripsi Sarjana Akuntansi pada Fakultas Ekonomi dan Bisnis Universitas Pendidikan Ganesha.

BIBLIOGRAPHY Asri Dwija Putri, I., \& Aryastha Mahaendrayasa, P. 2017. Pengaruh Prinsip-Prinsip Good Corporate Governance Terhadap Kinerja Keuangan Lembaga Perkreditan Desa (LPD) Di Kota Denpasar. E-Jurnal Akuntansi Universitas Udayana, 21(2). 970-995.

Badung, B. A. 2015. Profil LPD Kabupaten Badung. Mangupura, Profil LPD Kabupaten Badung.

Bagiada, I. M. 2017. Analisis Kesehatan Lembaga Perkreditan Desa (LPD) Studi Kasus Pda LPD Desa Adat Kedonganan Kuta - Badung Tahun 2013-2015. Jurnal ACSY Politeknik Sekayu, 6(2), 3-6.

Benhart, U., \& Rosenstein. 1998. Board Composition, Managerial Ownership, and Firm Performance: An Empirical Analysis. Financial Review 33, 1-16.

Bulandari, W. I., \& Damayanthi, E. I. 2014. Pengaruh Prinsip-Prinsip Good Corporate Governance Pada Kinerja Keuangan Lembaga Perkreditan Desa Di Kabupaten Badung. E-Jurnal Akuntansi Universitas Udayana, 8(3). 641-659.

Candra Andreana, M., \& Ary Wirajaya, I. 2018. Pengaruh Transparancy, Accountability, Responsibility, Independency, dan Fairness Pada Kinerja 
Keuangan Lembaga Perkreditan Desa. E-Jurnal Akuntansi Unoversitas Udayana, 23(2). 1305-1331.

Clemente, A., \& Labat, B. 2009. The Role Of Independent Directors In The. International Journal Of Accounting Information System, 5. 1-50.

Dewi, K. K. 2014. Pengaruh Penerapan Prinsip-Prinsip Good Corporate Governance Pada Kinerja Keuangan Lembaga Perkreditan Desa Kabupaten Gianyar.Skripsi Sarjana pada Fakultas Ekonomi Dan Bisnis Universitas Udayana.

Erawati, N. A., \& Baskara Sastra, I. M. 2017. Pengaruh Penerapan Good Corporate Governance dan Tri Hita Karana Pada Kinerja Keuangan Lembaga Perkreditan Desa (LPD) (Studi Kasus LPD Se-Kecamatan Abiansemal). E-Jurnal Akuntansi Universitas Udayana, 421-451.

Forum for Corporate Governance in Indonesia (FCGI) . 2001. Seri Tata Kelola Perusahaan (Corporate Governance). Jakarta.

Frediawan, R. 2008. Pengaruh Penerapan Prinsip Good Corporate Governance Terhadap Kinerja Keuangan Perusahaan (Studi Kasus pada Pt Jamsostek Kantor Cabang II Bandung). Skripsi Sarjana Akuntansi pada Fakultas Ekonomi Universitas Widyatama Bandung.

Ghozali. 2016. Aplikasi Analisis Multivariate dengan Program SPSS. Badan Penerbit Universitas Diponogoro.

Hart, O. 1995. Corporate Governance : Some Theory and Implications. The Economic Journal, 105(430), 211-217.

Hendra Jatjaya, I. W. 2014. Pengaruh Tingkat Pengungkapanm CSR dan Mekanisme GCG Pada Kinerja Keuangan Perusahaan Pertambangan. EJurnal Akuntansi Universitas Udayana, 8(3), 620-629.

Hill, C. W., \& Jones, T. M. 1992. Stakehplders-Agency Theory. Jurnal Of Manajemen Studies, 131-154.

Hindistari, R. R. 2016. Pengaruh Penerapan Prinsip-Prinsip Good Corporate Governance Pada Kinerja Bank Perkreditan Rakyat Kabupaten Gianyar. EJurnal Akuntansi Universitas Udayana,16(1), 101-128.

Indonesia, I. A. 2001. Standar Profesional Akuntan Publik. Jakarta: Salemba Empat.

Irmala, S. 2010. Pengaruh Mekanisme Good Corporate Governance Terhadap Kinerja Perbankan Nasional (Studi Pada Perusahaan Perbankan yang Terdaftar di Bursa Efek Indonesia Periode 2006-2008). SkripsiSarjana pada Fakultas Ekonomi Universitas Diponegoro.

Jayanti, I. F. 2016. Pengaruh Good Corporate Governance Terhadap Kinerja (Studi Pada Karyawan PT Pos Indonesia (Persero) Tuban). Jurnal Administrasi Bisnis (JAB), 32(1), 82-89. 
Kabar Nusa. 2017. Tingkat Kesehatan LPD Kabupaten Badung. Kabarnusa.com: http://www.kabarnusa.com/2017/04/kekayaan-lpd-di-bali-capai-rp155triliun.html. Diakses Pada 29 April 2018

Kharisma, B. 2014. Good Corporate Governance Sebagai Suatu Konsep dan Mengapa Penting dalam Sektor Publik dan Swasta (Suatu Pendekatan Ekonomi Kelembagaan). Jurnal Buletin Studi Ekonomi Universitas Udayana, 9-30.

Krismaya, K. D. 2014. Pengaruh Penerapan Prinsip-Prinsip Good Corporate Governance Pada Kinerja Keuangan Lembaga Perkreditan Desa Kabupaten Gianyar Bali. E-Jurnal Akuntansi Universitas Udayana, 7(3), h:559-573.

Lacker, D. D., A, S., Richardson, \& Tuna, I. 2007. Corporate Governance, Accounting Outcomes and Organizational Performance. The Accounting Review, 82(4), 936-1008.

Mahaendrayasa, K. A., \& Putri, A. D. 2017. Pengaruh Prinsip-prinsip Good Corporate Governance Terhadap Kinerja Keuangan Lembaga Perkreditan Desa (LPD) Di Kota Denpasar. E-Jurnal Akuntansi Universitas Udayana, 970-995.

Mangkunegara, \& Prabu, A. 2005. Evaluasi Kinerja SDM. In Evaluasi Kinerja $S D M$ (p. 67). Bandung: Refika Aditama.

Meitradi, K. S., \& Asri Dwija Putri, I. A. 2016. Pengaruh Good Corporate Governance Terhadap Kinerja Keuangan Lembaga Perkreditan Desa di Kecamatan Mengwi Kabupaten Badung. E-Jurnal AKuntansi Universitas Udayana, 5(3), 586-596.

Mohd Hassan, C. H., Rashidah, A. R., \& Mahenthiran, S. 2009. The Power of Good Corporate Governance : Teori Impelementasi. Managerial Auditing Journal, 23(8), 744-778.

Muh, A. E. 2009. The Power of Good Corporate Governance : Teori dan Implementasi. Jakarta: Salemba Empat.

Mulyadi. 2007. Sistem Perencanaan dan Pengendalian Manajemen. Jakarta: Salemba Empat.

Purwani, T. 2010. Pengaruh Good Corporate Governance Terhadap Kinerja Perusahaan. Majalah Ilmiah Informatika, 1(2), h:47-60.

Putri, I. A., \& Ulupui, I. 2017. Pengantar Corporate Governance. Denpasar: CV. Sastra Utama.

Rahmatika, N. 2015. Pengaruh Penerapan Prinsip-Prinsip Good Corporate Governance Terhadap Kinerja Keuangan Perusahaan (Studi pada PT Angkasa Pura II). Jurnal Akuntansi Universitas Riau, 3(2), 148-159. 
BIBLIOGRAPHY Rambo, C. 2013. Influence Of The Capital Markets Authority's Corporate Governance Guildelines On Financial Performance Of Commercial Banks In Kenya Charles. The International Journal Of Business And Finance Research, 3(11), 878-893.

Ristifani. 2009. Analisis Implementasi Prinsip-Prinsip Good Corporate Governance (GCG) Dan Hubungannya Terhadap Kinerja PT Bank Rakyat Indonesia (Persero) Tbk. Jurnal Mahasiswa Fakultas Ekonomi, Universitas Gunadarma.

Sandraningsih, N., \& Putri, I. A. 2015. Pengaruh Prinsip-Prinsip Good Corporate Governance Pada Kinerja Keuangan Lembaga Perkreditan Desa Kecamatan Abiansemal. E-Jurnal Akuntansi Universitas Udayana, 3(11). 878-893.

Setyawan, K. M. 2013. Pengaruh Good Corporate Governance Terhadap Kinerja Keuangan Lembaga Pekreditan Desa Di Kecamatan Mengwi Kabupaten Badung.Skripsi Sarjana pada Fakultas Ekonomi dan Bisnis Universitas Udayana.

Sugiyono. 2014. Metode Penelitian Bisnis. Bandung: CV. Alfabeta.

Sugiyono. 2017. Metode Penelitian Kuantitatif, kualitatif, dan R\&D. Bandung: Alfabeta.

Shleifer, A., \& Vishny, R. 1997. Survey of Corporate Governance. Journal Of Finance Volume, 52(2).

Wiagustini, N. L. 2014. Manajemen Keuangan. Denpasar: Udayana University Press.

Yaghoobnezhad, A., Nikoomaram, H., \& Salteh, H. M. 2012. The Investigation of The Relationship Between Corporate Governance and Earnings Quality. African of Business Management, 6(11), 3898-3912.

Yazdanfar, D. 2013. Profitability determinants among micro firms : Evidence from swedish data. International Journal of Managerial Finance, 151160.

Waddock, S., \& Graves, S. 1997. The Corporate Social Performance - Financial Performance Link. Strategic Management Journal, 18(4). 303-319.

Windah, C. 2013. Pengaruh Penerapan Corporate Governance Terhadap Kinerja Keuangan Perusahaan Hasil Survei The Indonesian Institute Perpection Governance (IIGC) Periode 2008-2011. Jurnal Ilmiah Mahasiswa Universitas Surabaya, 2(1). 1-20. 